\title{
Correction to: Influence of aging on brain and web characteristics of an orb web spider
}

\author{
Alain Pasquet $^{1,3} \cdot$ Camille Toscani $^{2} \cdot$ Mylène Anotaux $^{1}$
}

Published online: 8 January 2019

(c) The Author(s) 2019

\section{Correction to: Journal of Ethology (2018) 36:85-91 https://doi.org/10.1007/s10164-017-0530-z}

The article Influence of aging on brain and web characteristics of an orb web spider, written by Alain Pasquet, Camille Toscani and Mylène Anotaux was originally published electronically on the publisher's internet portal (currently SpringerLink) on 23 November, 2017 without open access. With the author(s)' decision to opt for Open Choice the copyright of the article changed on 18 December, 2018 to (C) The Author(s) 2018 and the article is forthwith distributed under the terms of the Creative Commons Attribution 4.0 International License (http://creativecommons.org/ licenses/by/4.0/), which permits use, duplication, adaptation, distribution and reproduction in any medium or format, as long as you give appropriate credit to the original author(s) and the source, provide a link to the Creative Commons license and indicate if changes were made.

The original article has been corrected.

Open Access This article is distributed under the terms of the Creative Commons Attribution 4.0 International License (http://creativecommons.org/licenses/by/4.0/), which permits unrestricted use, distribution, and reproduction in any medium, provided you give appropriate credit to the original author(s) and the source, provide a link to the Creative Commons license, and indicate if changes were made.

The original article can be found online at https://doi.org/10.1007/ s10164-017-0530-z.

Alain Pasquet

alain.pasquet@univ-lorraine.fr

1 Faculté des Sciences et Techniques, University of Lorraine, UR AFPA, USC INRA n ${ }^{\circ} 340$, BP 239, Bld des Aiguillettes, 54506 Vandoeuvre-Les-Nancy, France

2 University of Paris-Est, Ecole nationale vétérinaire d'Alfort, UMR 7179 CNRS MNHN, 94704 Maisons-Alfort, France

3 CNRS, National Centre for Scientific Research, Paris, France 